\title{
Icelandic lampreys (Petromyzon marinus): where do they come from?
}

\author{
Ana M. Pereira $\cdot$ Benony Jonsson • Magnus Johannsson • \\ Joana I. Robalo $\cdot$ Vítor C. Almada
}

Received: 23 May 2011/Revised: 4 September 2011/Accepted: 5 September 2011/Published online: 9 November 2011

(C) The Ichthyological Society of Japan 2011

\begin{abstract}
The recent discovery of sea lamprey wounds on salmonids in Icelandic rivers prompted an investigation on the origin of sea lampreys in Icelandic waters. Using a mitochondrial DNA fragment, the origin of the lampreys examined was assigned to the European stock and not to the North American one.
\end{abstract}

Keywords Petromyzon marinus $\cdot$ Iceland $\cdot$ Mitochondrial control region $\cdot$ Preying adults in rivers

\section{Introduction}

The sea lamprey, Petromyzon marinus, occurs on both sides of the North Atlantic, where they are represented by distinct stocks (Rodriguez-Muñoz et al. 2004) in latitudes from $72^{\circ} \mathrm{N}$ to $25^{\circ} \mathrm{N}$ (Kelly and King 2001). In North America, its distribution ranges from Newfoundland to Florida (including some inland waters), and in Europe from Norway to the Mediterranean (Kelly and King 2001; Waldman et al. 2006). This anadromous lamprey migrates into rivers where it spawns in nests dug in gravel beds, dying after a short period. The larvae are carried

A. M. Pereira $(\bowtie)$ · J. I. Robalo · V. C. Almada

Eco-Ethology Research Unit, ISPA,

Rua Jardim do Tabaco 34, 1149-041 Lisboa, Portugal

e-mail: ana_pereira@ispa.pt

\section{A. M. Pereira}

CIMAR/CIIMAR, Oporto University,

Rua dos Bragas 289, 4050-123 Porto, Portugal

B. Jonsson · M. Johannsson

Institute of Freshwater Fisheries, Keldnaholti,

112 Reykjavík, Iceland downstream until they reach suitable muddy/sandy substrata where they stay buried in the sediment for several years, filter feeding on particles carried by the moving water (Maitland 2003). After the larval stage, the young lampreys, which acquire fully functional eyes and become active swimmers, migrate to the sea, where they live at least 2 years, biting and sucking blood and other tissues from fish (Hardisty 2006). In North America the presence of this species became a serious problem after the invasion of the Great Lakes and the establishment of populations that complete the entire life cycle in freshwater. They caused very serious declines in several prey species, namely salmonids (Schneider et al. 1996). In Europe, according to the IUCN, the conservation status of this species is the least concern. However, in Western Europe, its conservation status is raising increasing concerns (Maitland 2003).

In the marine waters off Iceland, there have been sporadic records of the parasitic stage of this species, at least since the nineteenth century (Sæmundsson 1926). However, there are no records of reproduction of the species in Icelandic freshwaters and no reports of parasitic lampreys entering rivers (Jónsson and Jóhannsson 2008). In 2006, the presence of sea lamprey wounds in returning sea trout (Salmo trutta) caught in freshwater in southeastern Iceland was reported to the Institute of Freshwater Fisheries, Iceland. It was confirmed by the Institute that sea lamprey wounds were present in trout in several Icelandic rivers. In 2006, three lampreys were caught in marine waters at the south coast, and one was found preying on newly returned salmon (Salmo salar) in freshwater in the Ytri Rangá River $\left(63^{\circ} 49.091^{\prime} \mathrm{N}, 20^{\circ} 25.097^{\prime} \mathrm{W}\right.$ ) (Fig. 1). This is the first record of sea lamprey attacking returning salmonids in Iceland and the first record of this species in Icelandic freshwater. This record deserves special attention because 
while typically lampreys entering freshwater to spawn do not feed, this specimen was collected while feeding in the river.

In order to understand the origin of these lampreys, in this article, a 624-bp fragment of mtDNA of non-coding region I from the four specimens described above was sequenced.

\section{Materials and methods}

DNA sequences were obtained from ethanol-preserved fin clips from four adult lampreys collected in Icelandic water, three in marine waters, and one found preying on newly returned salmon in freshwater in the Ytri Rangá River $\left(63^{\circ} 49.091^{\prime} \mathrm{N}, 20^{\circ} 25.097^{\prime} \mathrm{W}\right)$ (Fig. 1). The lampreys were caught by local fisherman, frozen, and delivered to the Institute of Freshwater Fisheries, Iceland, where they were deposited. Total genomic DNA was extracted with a REDExtract-N-Amp kit (Sigma-Aldrich, http://www.sigma.com). PCR primers used were LampFor 5'-ACA CCC AGA AAC AGC AAC AAA-3 $3^{\prime}$ and LampRev 5'-GCT GGT TTA CAA GAC CAG TGC-3' (Almada et al. 2008). PCR conditions followed Almada et al. (2008). Sequencing reactions were performed in StabVida (Lisbon) on a 3700 ABI DNA sequencer (Applied Biosystems) using the Big Dye terminator DNA sequencing kit (http://www.stabvida.com). A 624-bp fragment of mtDNA from the control region (non-coding region I, according to Blank et al. 2008) was sequenced from the four specimens collected (GenBank accession nos. HM245344, HM245345, HM245346, and HM245347).

Sequences were aligned with Clustal X (Thompson et al. 1997) and were compared with all available sequences (Waldman et al. 2006; Almada et al. 2008). The mtDNA fragment used includes the region sequenced by Almada et al. (2008) for the European sea lampreys and Waldman et al. (2006) for the North American ones. Distances among haplotypes were computed using PAUP $4.0 \mathrm{~b} 10$ (Swofford 2003).

\section{Results and discussion}

The four analyzed sequences of Petromyzon marinus from Iceland correspond to the same haplotype. This haplotype (PMVG8) was already found by Almada et al. (2008). It was present in 213 individuals out of the 273 analysed in that study, and it was present in samples from the Rhine in Germany to the Guadiana in south Portugal. In order to compare the European haplotypes with the ones obtained by Waldman et al. (2006) from North America, European sequences were truncated to make them homologous with the fragment obtained from American fish. Nine haplotypes from Europe remained, all different from the 18 found in West Atlantic drainages by Waldman et al. (2006). Indeed, the average uncorrected $p$ distance between the haplotype found in Iceland and the European haplotypes is $0.37 \%$ (standard deviation, 0.13) and with the North-American
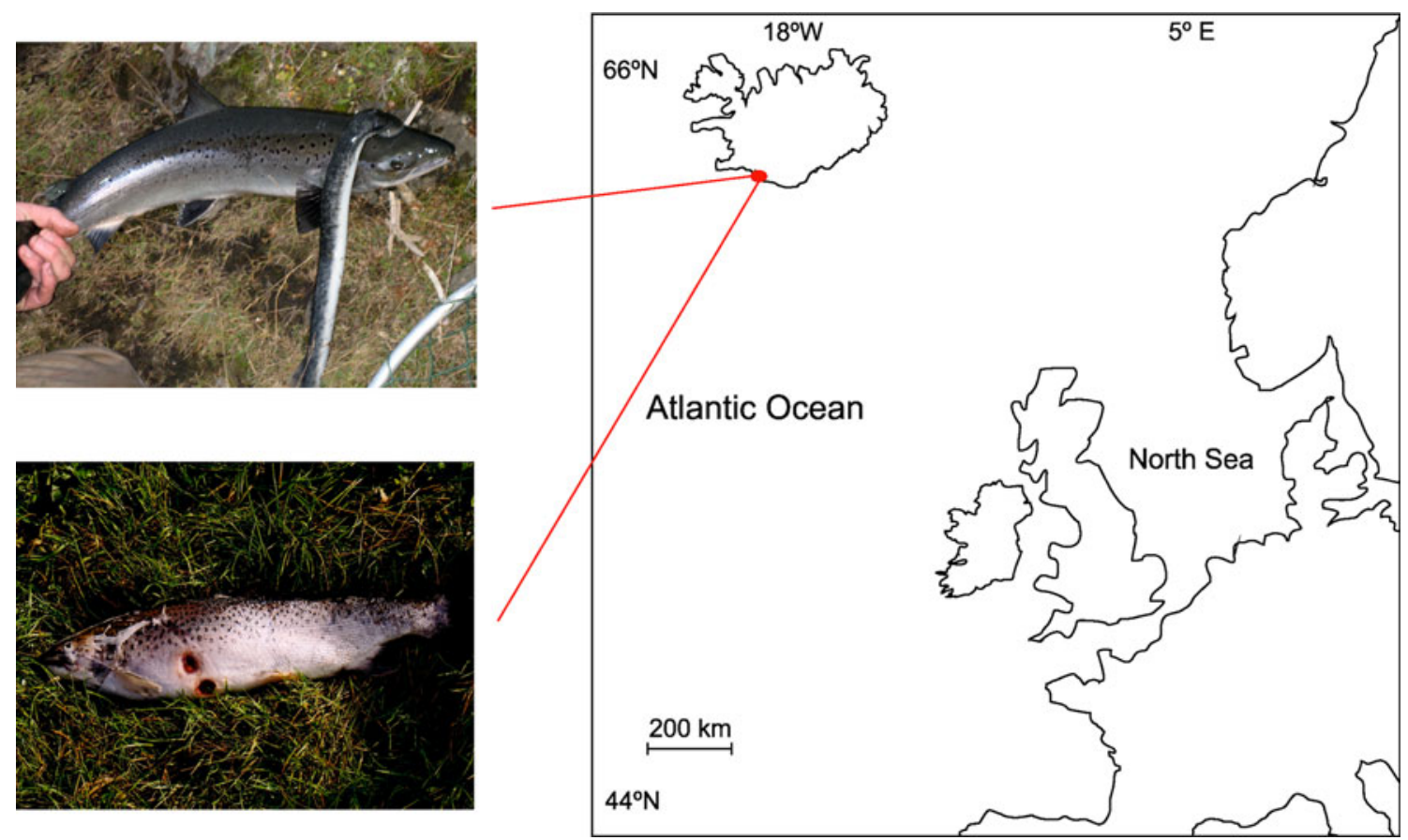

Fig. 1 Map with collection site location and photographs of a lamprey preying on a salmon (upper) and a salmon with lamprey wounds (bottom) 
haplotypes $1.2 \%$ (standard deviation, 0.32). The American haplotype displaying the smallest uncorrected distance to the haplotype found in Iceland is at a distance of $0.6 \%$.

Our data support the conclusion that sea lampreys from Iceland belong to the European stock of this species. The finding of the same haplotype along Europe, from Portugal to Iceland, is in line with the conclusions of Almada et al. (2008). These authors, using the same marker, found that no population differentiation could be detected along West Europe. The lack of structure was interpreted as the result of long migrations in the ocean, combined with poor or no homing. Interestingly, Goodman et al. (2008) found a very similar pattern for another migratory lamprey, Entosphenus tridentatus, in the North American Pacific and interpreted it in a similar way. In the future, it would be interesting to see if this type of phylogeographic pattern holds for other lampreys that spend long periods in the sea.

The findings of this study are concordant with what is known for the Icelandic fish fauna as a whole. Briggs (1995) found that the dominant biogeographic relationships of the Icelandic fauna are with the Eastern Atlantic. Concerning the migratory fish, the occurrence of natural hybrids between European Anguilla anguilla and American eel Anguilla rostrata has been shown in Iceland (Albert et al. 2006). In the salmonids, apart from species that occur at both sides of the Atlantic, as Salvelinus alpinus and Salmo salar, the European Salmo trutta, is also found in Iceland. Two other migratory species found in Iceland also came from eastern Atlantic stock-Alosa fallax and Acipenser sturio (Jonsson 1992). At present, there is not enough information on the patterns and causes of largescale movements of sea lampreys in the sea to provide a full explanation, but the presence of Arctic conditions to the west, namely in Greenland (Briggs 1995), coupled with the influence of the Gulf stream in the eastern Atlantic, could explain the absence of lampreys of American origin in Iceland in the fish screened so far.

Two findings of this study deserve further investigation in the future: the increasing records of sea lamprey and the documented occurrence of a lamprey entering freshwater while attacking a salmon. It would be interesting to study in the future to what extent the increasing attacks by sea lamprey in Iceland are coupled with the oceanographic changes that are taking place at high latitudes. The finding of a sea lamprey entering freshwater while preying on a salmon indicates that at least in some conditions, lampreys can move to freshwater while still feeding. The presence of this species in rivers needs to be monitored in the future in order to evaluate if this species is spawning in Icelandic rivers, establishing local larval populations.

Acknowledgments This work was supported by a grant from Iceland, Liechtenstein, and Norway through the EEA Financial
Mechanism and the Norwegian Financial Mechanism by the project MarinERA 'Marine phylogeographic structuring during climate change: the signature of leading and rear edge of range shifting populations' and by the Eco-Ethology Research Unit (331/94) Pluriannual financing program (Fundação para a Ciência e a Tecnologia; partially FEDER funded).

\section{References}

Albert V, Jónsson B, Bernatchez L (2006) Natural hybrids in Atlantic eels (Anguilla anguilla, A. rostrata): evidence for successful reproduction and fluctuating abundance in space and time. Mol Ecol 15:1903-1916

Almada VC, Pereira AM, Robalo JI, Fonseca JP, Levy A, Maia C, Valente A (2008) Mitochondrial DNA fails to reveal genetic structure in sea-lampreys along European shores. Mol Phylogenet Evol 46:391-396

Blank M, Jurss K, Bastrop R (2008) A mitochondrial multigene approach contributing to the systematics of the brook and river lampreys and the phylogenetic position of Eudontomyzon mariae. Can J Fish Aquat Sci 65:2780-2790

Briggs JC (1995) Global biogeography. Developments in palaeontology and stratigraphy. Elsevier, Amsterdam

Goodman DH, Reid SB, Docker MF, Haas GR, Kinziger AP (2008) Mitochondrial DNA evidence for high levels of gene flow among populations of a widely distributed anadromous lamprey Entosphenus tridentatus (Petromyzontidae). J Fish Biol 72:400-417

Hardisty MW (2006) Lampreys. Life without jaws. Ceredigion, UK, Forrest text

Jónsson B, Jóhannsson M (2008) Rannsóknir á landnámi sæsteinsuga (Petromyzon marinus) á Íslandi. Report from Institute of Freshwater Fisheries, VMST/0801:1-23

Jonsson G (1992) Islenskir fiskar. Fiolvi, Reykjavik

Kelly FL, King JJ (2001) A review of the ecology and distribution of three lamprey species, Lampetra fluviatilis (L.), Lampetra planeri (Bloch) and Petromyzon marinus (L.): a context for conservation and biodiversity considerations in Ireland. Proc Royal Ir Ac 101B:165-185

Maitland PS (2003) Ecology of the river, brook and sea lamprey. Conserving Natura 2000 Rivers Ecology Series No. 5. English Nature, Peterborough

Rodriguez-Muñoz R, Waldman JR, Grunwald C, Roy NK, Wirgin I (2004) Absence of shared mitochondrial DNA haplotypes between sea lamprey from North American and Spanish rivers. J Fish Biol 64:783-787

Schneider CP, Owens RW, Bergstedt RA, O'Gorman R (1996) Predation by sea lamprey (Petromyzon marinus) on lake trout (Salvelinus namaycush) in southern Lake Ontario, 1982-1992. Can J Fish Aquat Sci 53:1921-1932

Swofford DL (2003) PAUP*. Phylogenetic analysis using parsimony (*and other methods), version 4b.10. Massachusetts, Sinauer Associates

Sæmundsson B (1926) Fiskarnir (in Icelandic). Bókaverslun Sigfúsar Eymundssonar, Reykjavík

Thompson JD, Gibson TJ, Plewniak F, Jeanmougin F, Higgins DG (1997) The ClustalX windows interface: flexible strategies for multiple sequence alignment aided by quality analysis tools. Nucl Acid Res 24:4876-4882

Waldman JR, Grunwald C, Roy NK, Wirgin II (2006) Evaluation of the native status of sea lampreys in Lake Champlain based on mitochondrial DNA sequencing analysis. Trans Am Fish Soc 135:1076-1085 